\title{
THE EFFECTS OF COMPENSATION, NON-PHYSICAL WORKING ENVIRONMENT, AND WORK MOTIVATION TOWARDS EMPLOYEES' JOB SATISFACTION IN SANAN TEMPEH CHIPS INDUSTRIAL CENTER
}

\author{
Hanif Ananto Wibowo \\ Department of Management FEB UMM \\ E-mail: hanifanantowibowo@gmail.com
}

\begin{abstract}
This study aimed to describe the compensation, non-physical working environment, motivation, and employees' job satisfaction in Sanan Tempeh Chips Industrial Center, to figure out the simultaneous and partial effects of compensation, non-physical working environment, and motivation towards the employees' job satisfaction, and to know which one of the independent variables having the greatest influence on the dependent one. There were 100 employees of the production unit used as respondents. The data collection techniques used were Interview, Observation, and Questionnaire. The data were analyzed by Likert Scale, Classical Assumption Test, and Multiple Linear Regression. The findings showed that the variable of compensation was categorized as "good" while variables of non-physical working environment, motivation, and job satisfaction were categorized as "fair". Moreover, the variables of compensation, nonphysical working environment, and motivation significantly affected the variable of job satisfaction. The compensation significantly and positively affected the job satisfaction. Meanwhile, the compensation, non-physical working environment, and motivation partially affected the job satisfaction. Among all the independent variables, the non-physical working environment had the greatest influence towards the employees' job satisfaction.
\end{abstract}

Keywords: compensation, non-physical working environment, work motivation, job satisfaction

\section{PENDAHULUAN}

Persaingan di dalam dunia usaha saat ini semakin kompetitif, sehingga perusahaan dituntut untuk dapat mengoptimalkan semua sumber daya yang dimiliki mulai dari modal, mesin, sarana kerja, metode, bahan baku, material, pemasaran maupun sumber daya manusia. Karyawan dalam hal ini berfungsi sebagai penunjang tercapainya tujuan perusahaan yang memiliki pikiran, perasaan, dan keinginan yang mempengaruhi sikap terhadap pekerjaan yang dibebankan atau dilimpahkan. Sikap karyawan terhadap pekerjaan tersebut dikenal dengan istilah kepuasan kerja yang ditimbulkan oleh pekerjaan, lingkungan, dan kebutuhan.

Perusahaan yang tidak bisa memenuhi kepuasan kerja karyawannya akan berdampak negatif terhadap perusahaan. Salah satu dampaknya adalah karyawan menjadi malas dalam melaksanakan 
pekerjaan yang diindikasikan dari produkvitas karyawan yang menurun. Seperti banyaknya karyawan yang tidak masuk kerja tanpa disertai keterangan yang jelas, lingkungan kerja yang kurang kondusif dilihat dari hubungan antar karyawan yang belum kompak, dan kurangnya motivasi dan pengarahan yang diberikan oleh pimpinan terhadap karyawan, sehingga kinerja karyawan menjadi buruk dan asalasalan.

Handoko (2000), menyatakan bahwa kepuasan kerja merupakan keadaan emosional yang menyenangkan atau tidak menyenangkan dengan mana para karyawan memandang pekerjaan mereka. Perusahaan melakukan beberapa cara atau tindakan untuk memenuhi kepuasan kerja karyawan. Salah satu cara yang digunakan perusahaan untuk memenuhi kepuasan kerja karyawan adalah melalui kompensasi, (Handoko, 2000). Menurut Wursanto (2003), karyawan juga membutuhkan lingkungan kerja yang dapat memberikan kepuasan psikologis, seperti memiliki hubungan yang harmonis. Perusahaan juga melakukan cara berupa pemberian motivasi kepada karyawan untuk memenuhi kepuasan kerja karyawannya. Menurut Wursanto (2005), menyatakan bahwa motivasi kerja merupakan dorongan, keinginan, hasrat dan tenaga penggerak yang berasal dari diri manusia untuk berbuat atau untuk melakukan sesuatu.

Sentra Industri Keripik Tempe Sanan merupakan home industri yang bergerak dalam produksi kripik tempe khas malang. Menurut informasi, dalam menjalankan usahanya, Sentra Industri Keripik Tempe Sanan selalu berusaha untuk meningkatkan kinerja karyawannya. Meningkatnya kinerja karyawan itu dikarenakan pihak pemilik home industri yang selalu menjaga serta memenuhi kepuasaan kerja para karyawannya salah satunya dengan pemberian kompensasi seperti gaji, THR dan uang lembur, serta berusaha menciptakan lingkungan kerja yang kondusif untuk menjaga hubungan antar karyawan agar tetap harmonis dan memberikan motivasi kerja melalui pimpinan, agar karyawan semakin puas dalam bekerja dan menjadi loyal terhadap perusahaan.

Permasalahan juga timbul di Sentra Industri Kripik Tempe Sanan dalam usaha meningkatkan serta memenuhi kepuasan kerja karyawannya. Permasalahan dan fenomena yang terjadi pada karyawan bagian produksi mengenai timbulnya ketidakpuasan kerja karyawan adalah sebagai berikut: (1) Tingkat absensi yang cukup tinggi dikarenakan karyawan sering tidak masuk kerja tanpa disertai keterangan yang jelas. Berikut tabel absensi karyawan yang tidak masuk kerja. 
Tabel 1. Data karyawan bagian produksi yang tidak masuk kerja tanpa keterangan pada bulan Januari-Desember 2016

\begin{tabular}{cccccc}
\hline No & Bulan & Jumlah karyawan & Absensi & Keterangan & Presentase \% \\
\hline 1 & Januari & 100 & 7 & Alfa & $7 \%$ \\
2 & Februari & 100 & - & Alfa & - \\
3 & Maret & 100 & 6 & Alfa & $6 \%$ \\
4 & April & 100 & 6 & Alfa & $6 \%$ \\
5 & Mei & 100 & 7 & Alfa & $7 \%$ \\
6 & Juni & 100 & - & Alfa & - \\
7 & Juli & 100 & 7 & Alfa & $7 \%$ \\
8 & Agustus & 100 & 5 & Alfa & $5 \%$ \\
9 & September & 100 & 6 & Alfa & $6 \%$ \\
10 & Oktober & 100 & 7 & Alfa & $7 \%$ \\
11 & November & 100 & 5 & Alfa & $5 \%$ \\
12 & Desember & 100 & 6 & Alfa & $6 \%$ \\
\hline \multicolumn{7}{c}{ JUMLAH } \\
\hline
\end{tabular}

Dari Tabel 1 tersebut dapat diketahui bahwa tingkat absensi karyawan bagian produksi Sentra Industri Keripik Tempe Sanan yang tidak masuk kerja tanpa disertai keterangan cukup tinggi pada tahun 2016 sebesar 62\%, jika dibandingkan dengan standar absensi yang ditetapkan oleh Sentra Industri Keripik Tempe Sanan yaitu sebesar 50\% pada tahun 2016. (2) karyawan malas dalam melaksanakan pekerjaan yang di bebankan perusahaan dilihat dari produkvitas karyawan yang menurun.

Permasalahan lain juga timbul di Sentra Industri Keripik Tempe Sanan seperti, (3) kompensasi yang diberikan perusahaan seperti gaji sebesar Rp. 1.000.000,- THR dan uang lembur di nilai kurang oleh karyawan karena jika dibandingkan dengan UMR kota Malang sebesar Rp. 2.026.000,- masih di bawah UMR kota Malang dan biaya layak hidup yang cukup tinggi di kota Malang, (4) lingkungan kerja yang kurang kondusif yang dirasakan oleh karyawan dilihat dari hubungan karyawan yang belum kompak karena sistem kerja di Sentra Industri Kripik Tempe Sanan yang menggunakan sistem perpindahan antar karyawan dari satu home industri ke home industri yang lain, (5) pemimpin kurang terjun langsung dalam memberikan motivasi dan pengarahan, sehingga kinerja karyawan menjadi buruk dan asalasalan, (6) beberapa karyawan yang keluar dari pekerjaannya tanpa alasan yang jelas. Berikut tabel karyawan yang keluar dari pekerjaan tanpa alasan yang jelas. 
Tabel 2. Data karyawan bagian produksi yang keluar dari pekerjaan pada bulan Januari-Desember 2016

\begin{tabular}{cccccc}
\hline No & Bulan & Jumlah karyawan & Resign (keluar) & Keterangan & Presentase \% \\
\hline 1 & Januari & 100 & 5 & Tanpa keterangan & $5 \%$ \\
2 & Februari & 100 & - & - & - \\
3 & Maret & 100 & 7 & Tanpa keterangan & $7 \%$ \\
4 & April & 100 & - & - & - \\
5 & Mei & 100 & 5 & Tanpa keterangan & $5 \%$ \\
6 & Juni & 100 & 7 & Tanpa keterangan & $7 \%$ \\
7 & Juli & 100 & - & Tanpa keterangan & $6 \%$ \\
8 & Agustus & 100 & - & - & - \\
9 & September & 100 & 5 & Tanpa keterangan & $5 \%$ \\
10 & Oktober & 100 & 6 & Tanpa keterangan & $6 \%$ \\
11 & November & 100 & 6 & Tanpa keterangan & $6 \%$ \\
12 & Desember & 100 & JUMLAH & $42 \%$ \\
\hline \multicolumn{7}{c}{ RATA-RATA } \\
\hline
\end{tabular}

Dari Tabel 2 tersebut dapat diketahui bahwa jumlah karyawan bagian produksi di Sentra Industri Keripik Tempe Sanan yang keluar dari pekerjaannya tanpa alasan yang jelas cukup tinggi pada tahun 2016 sebesar $42 \%$, jika dibandingkan dengan standar yang ditetapkan oleh Sentra Industri Keripik Tempe Sanan yaitu sebesar 30\% pada tahun 2016.

Berdasarkan paparan di atas, maka peneliti ingin melakukan penelitian lebih lanjut mengenai hubungan kompensasi, lingkungan kerja non fisik, dan motivasi kerja terhadap kepuasan kerja

\section{TINJAUAN PUSTAKA}

Menurut Simamora (2006) kompensasi adalah bayaran yang diberikan perusahaan untuk dapat meningkatkan produkvitas para karyawan guna mencapai keunggulan yang kompetitif. Jenis kompensasi kompensasi terbagi menjadi dua yaitu Kompensasi finansial terdiri atas dua yaitu kompensasi langsung dan kompensasi tidak langsung (tunjangan) dan kompensasi no finansial terdiri atas karena karir yang meliputi aman pada jabatan, peluang promosi, dan pengakuan karya. Indikator- indikator kompensasi meliputi gaji, insentif, tunjangan dan fasilitas.

Menurut Sedarmayanti (2009), Lingkungan kerja non fisik adalah semua keadaan yang terjadi yang berkaitan dengan hubungan kerja, baik hubungan dengan atasan maupun hubungan sesama rekan kerja, ataupun hubungan dengan bawahan. beberapa unsur penting dalam pembentukan sikap dan perilaku karyawan dalam lingkungan kerja non fisik yaitu pengawasan, suasana kerja, sistem pemberian imbalan, perlakuan baik, rasa aman, hubungan serasi, dan perlakuan adil.

Menurut Handoko (2000), motivasi diartikan sebagai keadaan dalam pribadi seseorang yang mendorong keinginan individu untuk melakukan kegiatan - kegiatan tertentu guna mencapai tujuan. Motivasi kerja dalam penelitian ini menggunakan teori Alderferer (Teori ERG) yaitu existence needs, related needs, growth needs. Kepuasan kerja adalah perasaan senang atau tidak senang karyawannya terhadap 
pekerjaannya. Indikator-indikator kepuasan kerja yaitu kepuasan dengan gaji, kepuasan dengan pekerjaan, kepuasan dengan promosi, kepuasan dengan sikap atasan, dan kepuasan dengan rekan kerja.

Berdasakan penjelasan penomena dan kajian pustaka diatas, maka hipotesis penelitian ini yaitu,, diiduga ada pengaruh secara simultan antara kompensasi, lingkungan kerja non fisik dan motivasi kerja terhadap kepuasan kerja, serta diduga variabel kompensasi memiliki kontribusi terbesar terhadap kepuasan kerja karyawan.

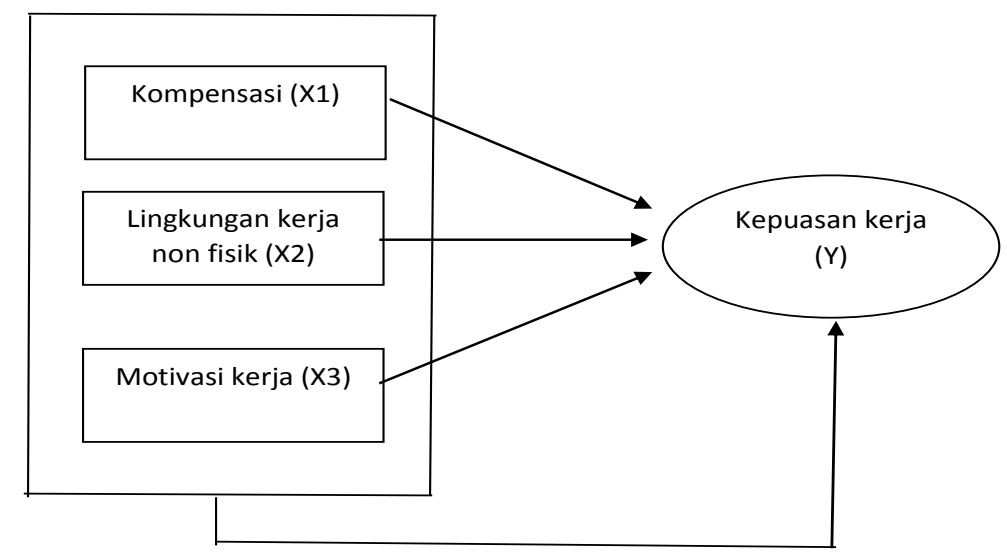

Gambar 1. Kerangka pemikiran

\section{METODE PENELITIAN}

Penelitian ini menggunakan metode survey, dimana peneliti juga melakukan observasi dalam pengumpulkan data tersebut. Populasi penelitian ini adalah seluruh karyawan bagian produksi Sentra Industri Keripik Tempe Sanan dengan jumlah 100 orang. Sampel dalam penelitian adalah karyawan yang bekerja di bagian produksi Sentra Industri Keripik Tempe Sanan yang berjumlah 100 orang sebagai responden, diperoleh dengan menggunakan teknik total sampling. Total sampling adalah teknik pengambilan sampel dimana jumlah sampel sama dengan jumlah populasi (sugiyono, 2007).

Penelitian ini menggunakan dua jenis variabel yaitu variabel independen (bebas) dan variabel dependen (terikat), dimana: variabel independen berupa kompensasi, lingkungan kerja non fisik, dan motivasi kerja, sedangkan variabel dependen berupa kepuasan kerja. Pengukuran variabel penelitian ini diukur dengan menggunakan skala likert.

Teknik pengumpulan data dalam penelitian ini menggunakan kuesioner. Data yang diperoleh kemudian dianalisis menggunakan rentang skala uji asumsi klasik analisis regresi linier berganda.

\section{HASIL DAN PEMBAHASAN}

Hasil analisis rentang skala yang digunakan untuk mengetahui kompensasi (X1), lingkungan kerja nonfisik (X2), motivasi kerja (X3), dan kepuasan karyawan (Y) pada para karyawan bagian produksi pada Sentra Industri Kripik Tempe Sanan dapat dilihat pada Tabel 3, 4, 5, dan 6 , sebagai berikut: 
Tabel 3. Hasil Rentang Skala Kompensasi (X1)

\begin{tabular}{|c|c|c|c|c|c|c|c|c|}
\hline \multirow[b]{2}{*}{ No } & \multirow[b]{2}{*}{ Item } & \multicolumn{5}{|c|}{ Skor Jawaban Responden } & \multirow[b]{2}{*}{ Skor Rentang Skala } & \multirow[b]{2}{*}{ Keterangan } \\
\hline & & STS & TS & $\mathrm{C}$ & $\mathrm{S}$ & SS & & \\
\hline 1. & $\mathrm{X} 1.1$ & 7 & 25 & 19 & 29 & 20 & 330 & Cukup \\
\hline 2. & $\mathrm{X} 1.2$ & 9 & 14 & 24 & 40 & 13 & 334 & Cukup \\
\hline 3. & $\mathrm{X} 1.3$ & 6 & 18 & 11 & 36 & 29 & 364 & Baik \\
\hline \multicolumn{7}{|c|}{ Total Skor Indikator } & 1.028 & \\
\hline \multicolumn{7}{|c|}{ Skor Rata-rata Rentang Skala } & 342.6 & Baik \\
\hline
\end{tabular}

Tabel 3. Menunjukkan bahwa kompensasi memiliki nilai rata-rata yang masuk dalam kriteria baik. Hal tersebut menunjukkan bahwa gaji yang diterima karyawan selama ini cukup sesuai dengan tanggung jawab yang diberikan dan juga sesuai dengan tingkat pendidikan karyawan, insentif yang selama ini diterima karyawan cukup sesuai dengan peraturan yang berlaku diperusahaan, tunjangan yang diterima karyawan selama ini sesuai dengan peraturan yang berlaku diperusahaan.

Tabel 4. Hasil rentang skala lingkungan kerja non fisik (X2)

\begin{tabular}{ccccccccc}
\hline \multirow{2}{*}{ No } & \multirow{2}{*}{ Item } & \multicolumn{8}{c}{ Skor Jawaban Responden } & \multirow{2}{*}{ Skor Rentang Skala } & \multirow{2}{*}{ Keterangan } \\
\cline { 3 - 6 } & & STS & TS & N & S & SS & Baik \\
\hline 1. & X2.1 & 3 & 20 & 17 & 38 & 22 & 356 & Baik \\
2. & X2.2 & 2 & 24 & 20 & 34 & 20 & 346 & Cukup \\
3. & X2.3 & 6 & 30 & 39 & 24 & 1 & 284 & Cukup \\
4. & X2.4 & 2 & 28 & 23 & 33 & 14 & 329 & Cukup \\
5. & X2.5 & 6 & 18 & 33 & 31 & 12 & 325 & Cukup \\
6. & X2.6 & 6 & 21 & 28 & 25 & 20 & 332 & Cukup \\
\hline \multicolumn{8}{c}{ Total Skor Indikator }
\end{tabular}

Tabel 4 menunjukkan bahwa lingkungan kerja non fisik menunjukan bahwa lingkungan kerja non fisik memiliki nilai rata-rata yang masuk dalam kriteria cukup. Hal tersebut menunjukkan bahwa pengawasan yang dilakukan secara kontinyu bisa diterima dengan baik oleh karyawan, suasana kerja di Sentra Industri Keripik Tempe Sanan baik, dan hubungan antar karyawan terjaga dengan harmonis serta karyawan mendapat perlakuan adil di sentra industri keripik tempe sanan.

Tabel 5. Hasil Rentang Skala motivasi kerja (X3)

\begin{tabular}{|c|c|c|c|c|c|c|c|c|}
\hline \multirow{2}{*}{ No } & \multirow{2}{*}{ Item } & \multicolumn{5}{|c|}{ Skor Jawaban Responden } & \multirow{2}{*}{ Skor Rentang Skala } & \multirow{2}{*}{ Keterangan } \\
\hline & & STS & TS & $\mathrm{N}$ & $\mathrm{S}$ & SS & & \\
\hline 1. & $\mathrm{X} 3.1$ & 7 & 22 & 22 & 47 & 2 & 315 & Cukup \\
\hline 2. & $\mathrm{X} 3.2$ & 11 & 27 & 28 & 32 & 2 & 287 & Cukup \\
\hline 3. & $\mathrm{X} 3.3$ & 11 & 23 & 26 & 34 & 6 & 301 & Cukup \\
\hline 4. & X3.4 & 9 & 32 & 25 & 31 & 3 & 287 & Cukup \\
\hline 5. & $\mathrm{X} 3.5$ & 13 & 24 & 26 & 34 & 3 & 290 & Cukup \\
\hline \multirow[t]{3}{*}{6.} & $\mathrm{X} 3.6$ & 11 & 29 & 24 & 32 & 4 & 289 & Cukup \\
\hline & \multicolumn{6}{|c|}{ Total Skor Indikator } & 1.769 & \\
\hline & \multicolumn{6}{|c|}{ Skor Rata-rata Rentang Skala } & 294.8 & Cukup \\
\hline
\end{tabular}


Tabel 5 menunjukkan bahwa bahwa motivasi kerja memiliki nilai rata-rata yang masuk dalam kriteria cukup. Hal tersebut menunjukkan bahwa pemberian motivasi berupa pemberian kebutuhan biologis, kebutuhan sosial dan kesempetan untuk menyampaikan ide-ide yang diberikan pemimpin selama ini cukup oleh karyawan.
Tabel 6. Menunjukan bahwa kepuasan kerja memiliki nilai ratarata yang masuk dalam kriteria cukup. Dengan demikian hal tersebut menunjukkan bahwa selama ini karyawaan di Sentra Industri Keripik Tempe Sanan cukup puas terhadap gaji, pekerjaan, motivasi, sikap atasan kepada karyawan dan rekan kerja.

Tabel 6. Hasil rentang skala kepuasan kerja (Y)

\begin{tabular}{|c|c|c|c|c|c|c|c|c|}
\hline \multirow{2}{*}{ No } & \multirow{2}{*}{ Item } & \multicolumn{5}{|c|}{ Skor Jawaban Responden } & \multirow{2}{*}{ Skor Rentang Skala } & \multirow{2}{*}{ Keterangan } \\
\hline & & STS & TS & $\mathrm{N}$ & $\mathrm{S}$ & SS & & \\
\hline 1. & Y1.1 & 11 & 23 & 20 & 34 & 12 & 313 & Cukup \\
\hline 2. & $\mathrm{Y} 1.2$ & 3 & 22 & 27 & 33 & 15 & 335 & Cukup \\
\hline 3. & Y1.3 & 5 & 23 & 30 & 29 & 13 & 322 & Cukup \\
\hline 4. & Y1.4 & 9 & 23 & 19 & 37 & 12 & 320 & Cukup \\
\hline \multirow[t]{3}{*}{5.} & Y1.5 & 5 & 19 & 29 & 30 & 17 & 335 & Cukup \\
\hline & \multicolumn{6}{|c|}{ Total Skor Indikator } & 1.625 & \\
\hline & \multicolumn{6}{|c|}{ Skor Rata-rata Rentang Skala } & 325 & Cukup \\
\hline
\end{tabular}

Dari hasil analisis regresi pada Tabel 7. dapat diketahui persamaan regresi berganda sebagai berikut: $\mathrm{Y}=0,943$ $+0,296 \mathrm{X} 1+0,348 \mathrm{X} 2+0,305 \mathrm{X} 3+\mathrm{e}$

Konstanta (a) bernilai 0,943 mengindikasikan bahwa, jika kompensasi, lingkungan kerja non fisik, dan motivasi kerja bernilai 0 , maka kepuasan kerja bernilai 0,943 . Hal ini bermakna jika tidak ada variabel kompensasi, lingkungan kerja non fisik, dan motivasi kerja maka kepuasan kerja akan sebesar 0,943 .

Variabel kompensasi dengan koefesien regresi sebesar 0,296. Jika variabel independent lain nilainya dianggap konstan atau nol maka kompensasi berpengaruh berpengaruh terhadap kepuasan kerja. Hal ini bermakna semakin baik kompensasi di Sentra Industri Kripik
Tempe Sanan maka semakin tinggi kepuasan kerja karyawan.

Variabel lingkungan kerja dengan koefisien regresi sebesar 0,348 . Jika variabel independent lain nilainya dianggap konstan atau nol maka lingkungan kerja non fisik berpengaruh terhadap kepuasan kerja. Hal ini bermakna semakin baik lingkungan kerja non fisik di Sentra Industri Kripik Tempe Sanan maka semakin tinggi kepuasan kerja karyawan. Variabel motivasi kerja dengan koefisien regresi sebesar 0,305 . Jika variabel independent lain nilainya dianggap konstan atau nol maka motivasi kerja berpengaruh terhadap kepuasan kerja. Hal ini bermakna semakin tinggi motivasi kerja di Sentra Industri Kripik Tempe Sanan maka semakin tinggi kepuasan kerja karyawan. 
Tabel 7. Hasil Analisis Regresi Linier Berganda

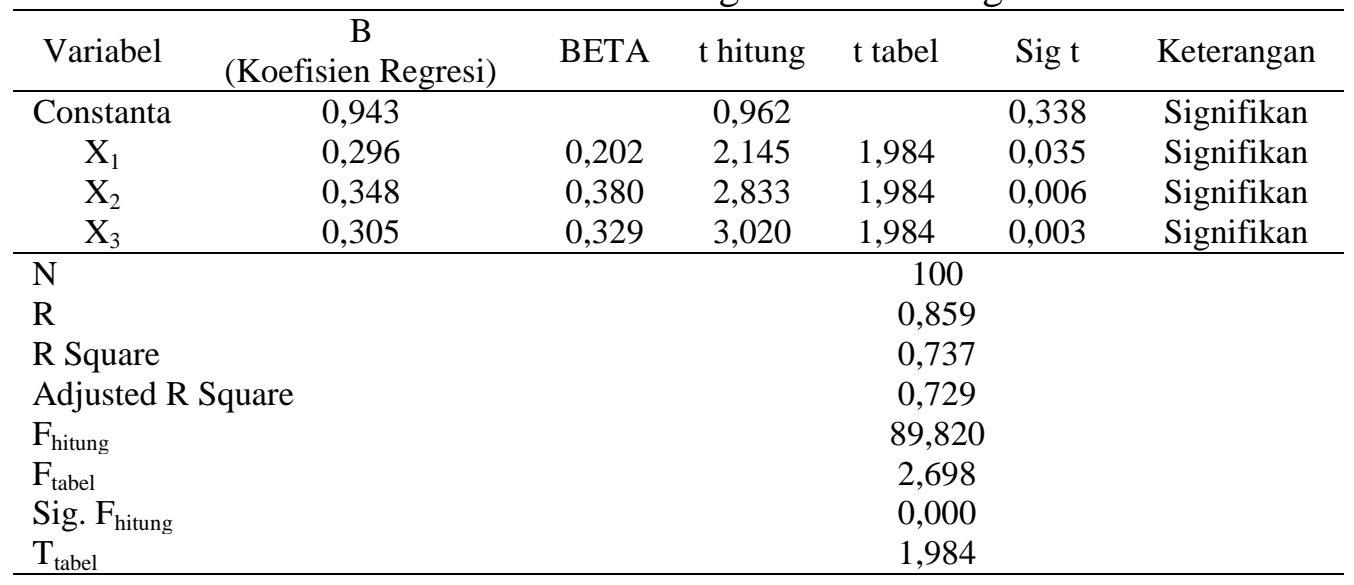

$\mathrm{e}=$ merupakan nilai residua tau kemungkinan kesalahan dari model persamaan regresi, yang disebabkan karena adanya kemungkinan variabel lainnya yang dapat mempengaruhi variabel kepuasan kerja pada sentra industri keripik tempe sanan tetapi tidak dimasukkan ke dalam model persamaan.

Angka R2 sebesar 0,737 menunjukkan bahwa $73,7 \%$ kepuasan kerja karyawan pada Sentra Industri Keripik Tempe Sanan dapat dijelaskan oleh variabel kompensasi, lingkungan kerja non fisik, dan motivasi kerja. Sedangkan, sisanya yaitu sebesar 26,3\% .dapat dijelaskan oleh variabel-variabel lainnya yang tidak dimasukkan ke dalam model.

Nilai koefisien korelasi berganda (R) diperoleh hasil sebesar 0,859 dimana hasil tersebut menggambarkan kuatnya hubungan kompensasi, lingkungan kerja non fisik, dan motivasi kerja secara bersama-sama terhadap variabel kepuasan kerja pada sentra industri kripik tempe sanan (Y). Hal ini berarti hubungan antara keseluruhan variabel independent dengan variabel dependent adalah erat karena nilai $\mathrm{R}$ tersebut di atas $50 \%$.
Berdasarkan hasil koefisien regresi berganda kompensasi, lingkungan kerja non fisik, dan motivasi kerja terhadap kepuasan kerja karyawan menunjukkan bahwa, semakin baik kompensasi maka semakin tinggi kepuasan kerja karyawan, semakin baik lingkungan kerja non fisik maka semakin tinggi kepuasan kerja karyawan dan semakin tinggi pemberian motivasi kerja maka semakin tinggi kepuasan kerja karyawan. Hal ini di perkuat oleh pendapat yang dikemukakan oleh Hasibuan (2006), menyatakan bahwa ada beberapa faktor yang mempengaruhi kepuasan kerja karyawan di antaranya adalah Balas jasa yang adil dan layak, Suasana dan lingkungan pekerjaan, pemberian nilai-nilai yang mempengaruhi individu untuk mencapai hal yang spesifik sesuai dengan tujuan individu.

Berdasarkan perhitungan regresi didapat nilai $\mathrm{F}$ hitung sebesar 89,820. Perbandingan nilai $\mathrm{F}$ hitung dan $\mathrm{F}$ tabel adalah $\mathrm{F}$ hitung $89,820>\mathrm{F}$ tabel 2,698. Berdasarkan hasil perbandingan yang telah dilakukan, maka dapat diambil kesimpulan bahwa hipotesis 1 diterima, Ho 
ditolak dan Ha diterima, yang menjelaskan bahwa kompensasi, lingkungan kerja non fisik, dan motivasi kerja secara simultan berpengaruh positif dan signifikan terhada kepuasan kerja karyawan pada Sentra Industri Keripik Tempe Sanan. Hal ini sesuai dengan penelitian yang dilakukan oleh Pande dan Utama (2014), menyatakan bahwa kompensasi, lingkungan kerja non fisik, dan motivasi kerja secara bersama-sama berpengaruh signifikan terhadap kepuasan kerja Karyawan Word Brand Factory (WBF) Kuta - Bali.

Berdasarkan uji t dapat diketahui bahwa variabel kompensasi, lingkungan kerja non fisik, dan motivasi kerja berpengaruh terhadap variabel kepuasan kerja dengan hasil $\mathrm{t}$ hitung $>\mathrm{t}$ tabel untuk kompensasi sebesar 2,145>1,984, untuk variabel lingkungan kerja non fisik sebesar $2,833>1,984$, sedangkan untuk motivasi kerja sebesar 3,020 > 1,984. Hal ini berarti Ho ditolak dan $\mathrm{Ha}$ diterima sehingga dapat disimpulkan bahwa secara parsial kompensasi, lingkungan kerja non fisik, dan motivasi kerja berpengaruh signifikan terhadap kepuasan kerja karyawan bagian produksi di Sentra Industri Keripik Tempe Sanan, maka hipotesis pertama diterima sedangkan hipotesis kedua ditolak. Hal ini di dukung dengan penelitian yang dilakukan oleh Pande dan Utama (2014), menyatakan bahwa kompensasi, lingkungan kerja non fisik, dan motivasi kerja secara parsial berpengaruh signifikan terhadap kepuasan kerja Karyawan Word Brand Factory (WBF) Kuta Bali.
Berdasarkan hasil uji dominan di atas menunjukan bahwa Hasil analisis regresi berganda menjelaskan bahwa variabel lingkungan kerja non fisik (X2) merupakan variabel yang memiliki pengaruh paling dominan. Hal tersebut dapat dilihat dari uji secara parsial terhadap variabel terikat. Dari analisis uji t (parsial) dapat diketahui bahwa variabel lingkungan kerja non fisik (X2) mempunyai beta 0,380 dengan $\mathrm{t}$ hitung 2,833 $>\mathrm{t}$ tabel 1,984 dan nilai signifikansi $0,006<0,05$ dari pada variabel bebas lainnya. Sedangkan variabel kompensasi (X1) mempunyai nilai beta 0,202 dengan $t$ hitung 2,145 > t tabel 1,984 dan nilai signifikansi $0,035<0,05$ dari variabel bebas lainnya. Sedangkan untuk variabel motivasi kerja (X3) ) mempunyai nilai beta 0,329 dengan $\mathrm{t}$ hitung 3,020 > t tabel 1,984 dan nilai signifikansi $0,003<0,05$ dari variabel bebas lainnya.

Berdasarkan penjelasan tentang angka $\mathrm{R}^{2}$ 0,737 menunjukan bahwa sebesar $73,7 \%$ kepuasan kerja karyawan dapat dijelaskan oleh variabel kompensasi, lingkungan kerja non fisik, dan motivasi kerja. Sedangkan, sisanya yaitu sebesar $26,3 \%$ dapat dijelaskan oleh variabel-variabel lainnya yang tidak dimasukkan ke dalam model. Nilai koefisien korelasi berganda (R) diperoleh hasil sebesar 0,859 dimana hasil tersebut menggambarkan kuatnya hubungan antara kompensasi, lingkungan kerja non fisik, dan motivasi kerja secara bersama-sama terhadap variabel kepuasan kerja pada Sentra Industri Keripik Tempe Sanan (Y). Dapat disimpulkan bahwa hubungan antara 
keseluruhan variabel independent dengan variabel dependent adalah erat karena nilai $\mathrm{R}$ tersebut di atas $50 \%$.

\section{SIMPULAN}

Berdasarkan pembahasan hasil penelitian yang telah dilakukan tentang pengaruh kompensasi, lingkungan kerja non fisik dan motivasi kerja terhadap kepuasan kerja karyawan pada Sentra Industri Keripik Tempe Sanan. Maka dapat disimpulkan hal-hal sebagai berikut: kompensasi di sentra industri keripik tempe sanan dengan kriteria baik, lingkungan kerja non fisik di sentra industri keripik tempe sanan dengan kriteria cukup, motivasi kerja di sentra industri keripik tempe sanan dengan kriteria cukup, kepuasan kerja di sentra industri keripik tempe sanan dengan kriteria cukup.

Kompensasi, lingkungan kerja non fisik, dan motivasi kerja berpengaruh terhadap kepuasan kerja karyawan bagian produksi di sentra industri keripik tempe sanan. Secara simultan kompensasi, lingkungan kerja non fisik, dan motivasi kerja berpengaruh signifikan terhadap kepuasan kerja karyawan bagian produksi di Sentra Industri Keripik Tempe Sanan. Secara parsial kompensasi, lingkungan kerja non fisik, dan motivasi kerja berpengaruh signifkan terhadap kepuasan kerja karyawan bagian produksi di Sentra Industri Keripik Tempe Sanan. Dari ketiga variabel bebas, variabel lingkungan kerja non fisik memiliki terbesar terhadap kepuasan kerja karyawan pada sentra industri keripik tempe sanan.

\section{DAFTAR PUSTAKA}

Handoko, T Hani. 2000. Manajemen Personalia Dan Sumber Daya Manusia. Edisi 2. BPFE, Yogyakarta.

Hasibuan , M. 2007. Manajemen Sumber Daya Manusia. Bumi Aksara. Jakarta.

Pande, N. N. P. I. P., dan I. W. M. Utama. 2014. "Pengaruh Kompensasi, Lingkungan Kerja Non Fisik, Dan Motivasi Kerja Terhadap Kepuasan Kerja Karyawan". E-Jurnal Manajemen Universitas Udayana, Vol. 3, No. 7, hlm: 1943.

Sedarmayanti. 2009. Sumber Daya Manusia dan Produktivitas Kerja. CV Mandar Maju. Bandung.

Simamora, Henry. 2004. Manajemen Sumber Daya Manusia Edisi III. Yogyakarta: STIE YKPN.

Wursanto, I. 2009. Dasar-Dasar Ilmu Organisasi. Yogyakarta: Andi Offset. 